\title{
Spray operation for hydrogen production from methanol over $\mathrm{Ni}-$ $\mathrm{Cu} / \mathrm{Al}_{2} \mathrm{O}_{3}$ catalysts
}

\author{
Yi-Kai Chih"1, Wei-Hsin Chen ${ }^{1,2,3, \text { * }}$ \\ ${ }^{1}$ Department of Aeronautics and Astronautics, National Cheng Kung University, Tainan 701, \\ Taiwan \\ ${ }^{2}$ Research Center for Smart Sustainable Circular Economy, Tunghai University, Taichung \\ 407, Taiwan \\ ${ }^{3}$ Department of Mechanical Engineering, National Chin-Yi University of Technology, \\ Taichung 411, Taiwan \\ *Corresponding author email: weihsinchen@gmail.com; chenwh@mail.ncku.edu.tw
}

\begin{abstract}
Hydrogen has a promising future as a depository of clean energy, and its development is an important research and development pathway. The present study confirms the applicability of $\mathrm{Ni}-\mathrm{Cu} / \mathrm{Al}_{2} \mathrm{O}_{3}$ composites in a methanol steam reforming process, which serves as an environmentally friendly and economical way of producing hydrogen. The high porosity and surface area allow greater contact between the reactants and the catalysts in the hydrogen production process. With a Taguchi orthogonal matrix design, the relative impact of a selected group of factors on hydrogen productivity was investigated. With a novel technique of ultrasonic sprays, the prepared $\mathrm{Ni}-\mathrm{Cu} / \mathrm{Al}_{2} \mathrm{O}_{3}$ catalysts were able to achieve $96.9 \%$ methanol conversion, 36.9 vol\% hydrogen concentration in the product gas, and $2.72 \mathrm{~mol} \cdot\left(\mathrm{mol} \mathrm{CH}_{3} \mathrm{OH}\right)^{-}$ ${ }^{1}$ hydrogen yield at $250{ }^{\circ} \mathrm{C}$
\end{abstract}

\section{Keywords}

Hydrogen production; nickel and copper; methanol steam reforming (MSR); ultrasonic sprays.

\section{Introduction}

Among the most promising sources of renewable energy, hydrogen has been a focal point of development not only because of its renewability but also due to the fact that hydrogen-powered cells produce nothing but water, which makes it an ideal source of clean energy. Yet, the production of hydrogen itself requires a great deal of electricity and therefore entails considerable costs. To address such an issue, the scientific community has invested plenty of resources into finding ways to increase conversion efficiency and reduce costs.

Presently, there are four main approaches for hydrogen production: (1) thermochemical methods such as natural gas reforming as well as gasification of coal and biomass [1]; (2) electrochemical methods [2]; (3) photocatalysis [3]; and (4) biological methods [4]. Among these approaches, thermochemical methods are of the greatest potential for large-scale, commercialized production, owing much to the fact that the heat required in such processes can be derived from industrial waste. Conventionally, as much as $96 \%$ of the world's hydrogen production by thermochemical methods has relied on methane as the hydrogen-supplying reactant [5]. Yet, since the storage of an unstable gas such as methane is difficult and expensive, safer and more economical ways of generating hydrogen are desirable [6].

Among methods producing hydrogen out of methanol, methanol steam reforming (MSR, see Eq. (1)) is one of the most efficient and widely adopted techniques [7]. Although MSR is the primary reaction intended for hydrogen production, which results in $3 \mathrm{~mol}\left(\mathrm{~mol} \mathrm{CH}{ }_{3} \mathrm{OH}\right)^{-1}$ of hydrogen and only 
$1 \mathrm{~mol}\left(\mathrm{~mol} \mathrm{CH} \mathrm{CH}_{3} \mathrm{OH}\right)^{-1}$ of carbon dioxide, counterproductive side reactions cannot be eliminated in such a dynamic process. These include methanol decomposition (Eq. (2)) and water-gas shift (Eq. (3)), both of which tend to produce $\mathrm{CO}$ in a high-temperature environment. To prevent $\mathrm{CO}$ from poisoning the fuel-cell anode, factors such as temperature and catalysts must be carefully controlled to suppress the cO-producing reactions.

$$
\begin{aligned}
& \mathrm{CH}_{3} \mathrm{OH}+\mathrm{H}_{2} \mathrm{O} \rightleftharpoons 3 \mathrm{H}_{2}+\mathrm{CO}_{2}, \Delta \mathrm{H}_{298}^{0}=49.5 \mathrm{~kJ} \mathrm{~mol}^{-1} \\
& \mathrm{CH}_{3} \mathrm{OH} \rightleftharpoons 2 \mathrm{H}_{2}+\mathrm{CO}, \Delta \mathrm{H}_{298}^{0}=90.1 \mathrm{~kJ} \mathrm{~mol}^{-1} \\
& \mathrm{H}_{2} \mathrm{O}+\mathrm{CO} \rightleftharpoons \mathrm{CO}_{2}+\mathrm{H}_{2}, \Delta \mathrm{H}_{298}^{0}=-41.2 \mathrm{~kJ} \mathrm{~mol}^{-1}
\end{aligned}
$$

In summary, hydrogen production by MSR using recycled heat and $\mathrm{Ni}-\mathrm{Cu}$ composite is environmentally friendly and economical. The present study seeks to produce hydrogen, a clean carrier of energy, by MSR with the technique of ultrasonic sprays and $\mathrm{Ni}-\mathrm{Cu} / \mathrm{Al}_{2} \mathrm{O}_{3}$ catalysts prepared in a template-free fashion. By employing an orthogonal matrix experimental design and the statistical analysis of variance, the researchers look to identify major factors bearing on hydrogen productivity while putting $\mathrm{Ni}-\mathrm{Cu} / \mathrm{Al}_{2} \mathrm{O}_{3}$ catalysts to use. These catalysts can be used as an economical alternative to noble metal catalysts for hydrogen production in an environmentally friendly MSR process.

\section{Material and Methods}

Preparation of $\mathrm{Ni}$ - $\mathrm{Cu}$ precursor with different Ni content

The $\mathrm{Ni}-\mathrm{Cu} / \mathrm{Al}_{2} \mathrm{O}_{3}$ catalysts were synthesized with a hydrothermal reconstructed method. $1.5 \mathrm{~g}$ of $\mathrm{Cu}\left(\mathrm{NO}_{3}\right)_{2}$ (Merck, >95\%) and $0.196 \mathrm{~g}$ of $\mathrm{Ni}\left(\mathrm{NO}_{3}\right)_{2}$ (Merck, >95\%) were dissolved in $100.0 \mathrm{~mL}$ of water. $2.53 \mathrm{~g}$ of activated alumina (Merck, $>95 \%$ ) was dispersed in $80.0 \mathrm{~mL}$ of water. The copper/nickel solution and $2.0 \mathrm{M} \mathrm{NaOH}$ were added to the alumina solution. The $\mathrm{pH}$ value of the mixed gel solution was maintained at 9.0 . After stirring for $2.0 \mathrm{~h}$, the gel solution was hydrothermally treated at $70^{\circ} \mathrm{C}$ for $24 \mathrm{~h}$. The $\mathrm{Ni}-\mathrm{Cu} / \mathrm{Al}_{2} \mathrm{O}_{3}$ samples were then obtained by filtration and drying. In this work, the $\mathrm{Ni}-$ $\mathrm{Cu} / \mathrm{Al}_{2} \mathrm{O}_{3}$ samples using $0.196 \mathrm{~g}, 0.392 \mathrm{~g}$ and $0.588 \mathrm{~g} \mathrm{Ni}\left(\mathrm{NO}_{3}\right)_{2}$ are donated as $\mathrm{Ni}-\mathrm{Cu}(10 \%) / \mathrm{Al}_{2} \mathrm{O}_{3}, \mathrm{Ni}-\mathrm{Cu}$ $(20 \%) / \mathrm{Al}_{2} \mathrm{O}_{3}$, and $\mathrm{Ni}-\mathrm{Cu}(30 \%) / \mathrm{Al}_{2} \mathrm{O}_{3}$, respectively.

\section{MSR system}

A quartz tube ( $30 \mathrm{~mm}$ i.d.) and an ultrasonic sprayer were used for the MSR reaction unit (Fig. 1). The ultrasonic sprayer was used to help disperse the methanol fuel. A layer of catalyst pellets (i.e., the catalyst bed) was packed in the quartz tube to trigger MSR. A K-type thermocouple was installed at the center of the catalyst bed to detect the reaction temperature. The quartz tube was wrapped with a standard heating tape (D98L-TIP80), which was covered with a layer of refractory ceramic fiber.

Experimental procedure

Catalyst pellets weighing $30 \mathrm{~g}$ were employed in each of the experiments, which were conducted with a temperature ranging from 250 to $300{ }^{\circ} \mathrm{C}$. The catalyst bed was preheated to the reaction temperature for better MSR performance. With the aid of the carrier gas, methanol was fed into the reaction tube and atomized by ultrasonic shock. To remove moisture in the product gas, the temperature in the condenser was controlled at $6^{\circ} \mathrm{C}$, while $170 \mathrm{~g}$ of silica gel beads were loaded in the dryer. Each of the experimental runs lasted longer than $42 \mathrm{~min}$ to ensure that the reaction reaches a steady state. Overall, the relative errors in gas concentrations, $\mathrm{H}_{2}$ yield, and methanol conversion were controlled below $3.5 \%$.

Based on the flow rate and concentrations of $\mathrm{CO}, \mathrm{CO}_{2}$, and $\mathrm{CH}_{4}$, the methanol conversion rate can be calculated by the following equation: 


$$
\mathrm{CH}_{3} \mathrm{OH} \text { conversion }(\%)=\left(\frac{\dot{n}_{\mathrm{CO}_{2}, \text { out }}+\dot{n}_{\mathrm{CO}, \mathrm{out}}+\dot{n}_{\mathrm{CH}_{4, \mathrm{out}}}}{\dot{n}_{\mathrm{CH}} \mathrm{OH}, \text { in }}\right) \times 100
$$

where $\dot{n}$ stands for the molar flow rate $\left(\mathrm{mol} \mathrm{min}^{-1}\right)$ and the subscripts "in" and "out" designate inflow and outflow, respectively.

In addition, the volume concentration of hydrogen was measured with the GC, which indicates gas concentration in terms of integral areas. To convert areas into comparable percentages, a calibration curve was created by linear regression based on data collected from five different $\mathrm{H}_{2}$ concentrations, namely $10,20,30,40$, and $50 \mathrm{vol} \%$. Since the concentration of hydrogen in percentage terms is affected by the amount of the carrier gas, the figures in percentage must once again be converted into mole ratios (Eq. (5)). With the resultant figures in percentage, $\mathrm{H}_{2}$ yield, our final indicator of hydrogen concentration in mol ratio terms, can be calculated according to Eq. (5). The $\mathrm{H}_{2}$ yield can be estimated from the molar flow rate of hydrogen $\left(\mathrm{mol} \mathrm{min}^{-1}\right.$ ) and $\dot{n}_{\mathrm{H}_{2}}$ by the following equation:

$$
\mathrm{H}_{2} \text { yield }\left(\mathrm{mol} / \mathrm{mol} \mathrm{CH}_{3} \mathrm{OH}\right)=\left(\frac{\dot{n}_{\mathrm{H}_{2}}}{\dot{n}_{\mathrm{CH}_{3} \mathrm{OH}}}\right)
$$

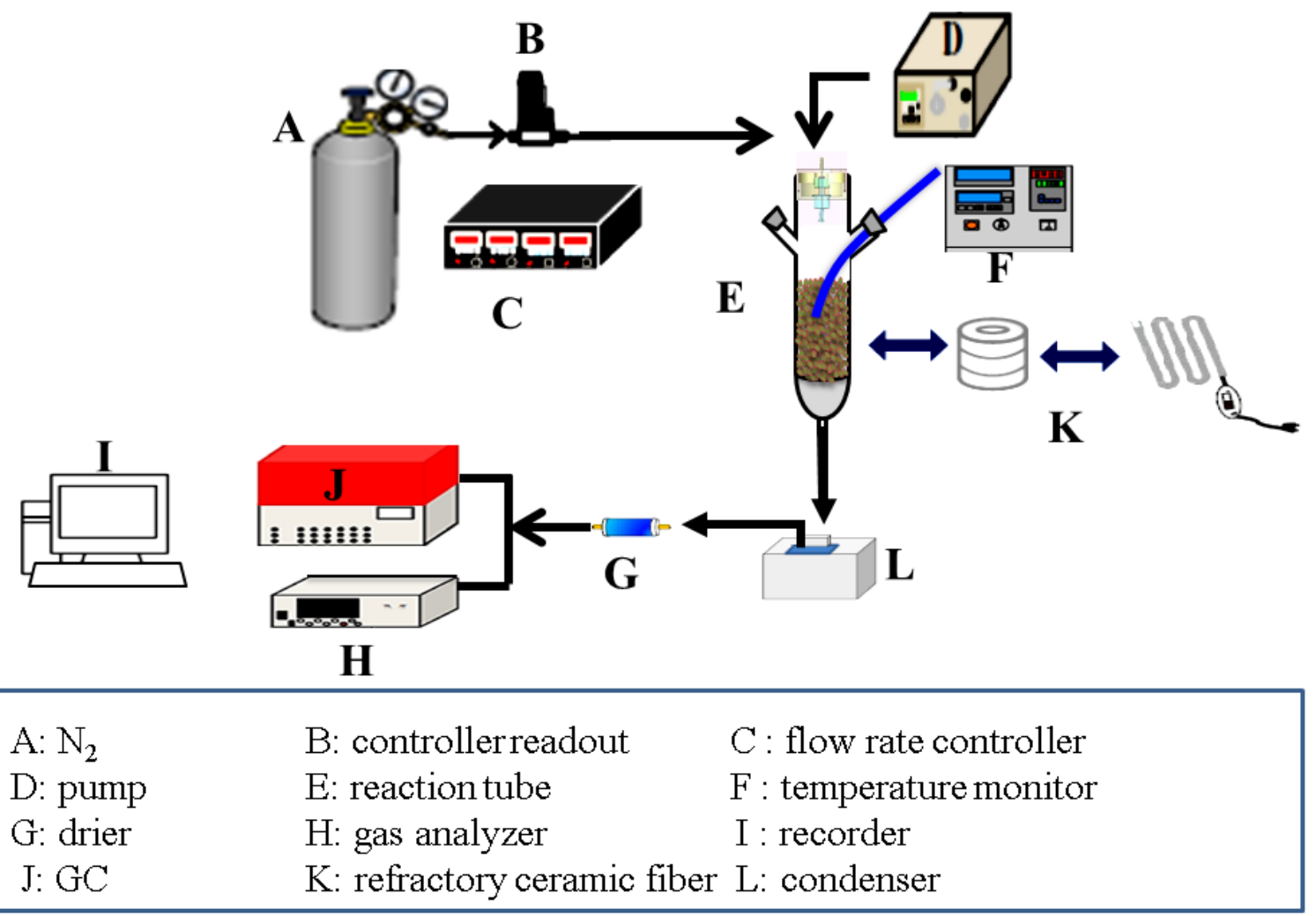

\section{Results and Discussion}

Figure 1. A schematic of the MSR system

In the final phase, the volume concentrations of $\mathrm{CO}_{2}, \mathrm{CO}$, and $\mathrm{CH}_{4}$ were measured with the $\mathrm{GA}$. The resultant figures in percentage were then converted into mole numbers, with which methanol conversion could be calculated (Eq. (4)). Figures of methanol conversion under various operating conditions are reported in Figs. 2 a, $\mathbf{b}$.

Results obtained under the operating condition of $\mathrm{S} / \mathrm{C}=1.5$ are shown in Fig. $2 \mathrm{a}$, where methanol conversion ranged between $59.33 \%$ and $100 \%$. Cases 5,7 , and 9 have achieved conversion above $90 \%$ corresponding to a high reaction temperature of $300{ }^{\circ} \mathrm{C}$ and a low carrier gas flow rate of 1,000 
$\mathrm{mL} \cdot \mathrm{min}^{-1}$. Nevertheless, the highest conversion (94.79\%) was achieved by Case 7 , whose reaction temperature was not the highest $\left(250^{\circ} \mathrm{C}\right)$. This may be a result of higher Ni concentration in the composite catalyst used in this particular case.

Figure $\mathbf{2 b}$ shows the results obtained under the operating condition of $S / C=2.0$, where the number of cases achieving high methanol conversion (defined as $>90 \%$ ) increased. The operating parameters of Cases 10,13,14, 16, and 17 suggest that methanol conversion increases significantly at reaction temperatures over $250{ }^{\circ} \mathrm{C}$. These results suggest that higher steam to carbon ratio is conducive to hydrogen production, for increased supply of $\mathrm{H}_{2} \mathrm{O}$ enables the full reaction of methanol through Eqs. (1) and (3).

(a) $\mathrm{CH}_{3} \mathrm{OH}$ conv., $\mathrm{S} / \mathrm{C}=1.5$

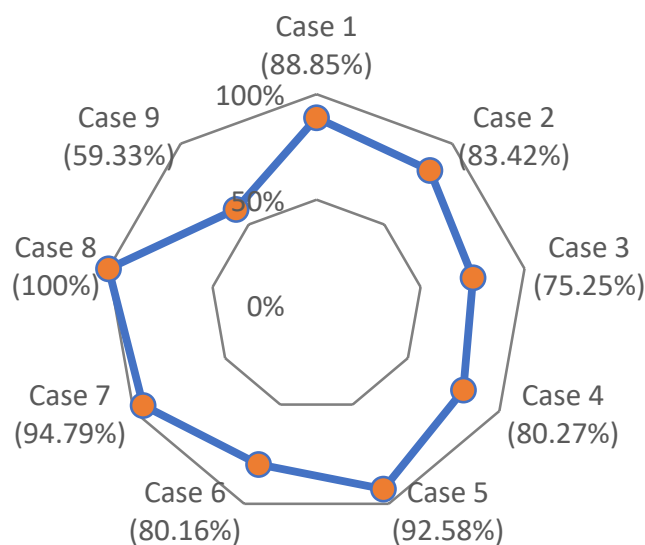

(b) $\mathrm{CH}_{3} \mathrm{OH}$ conv., $\mathrm{S} / \mathrm{C}=2.0$

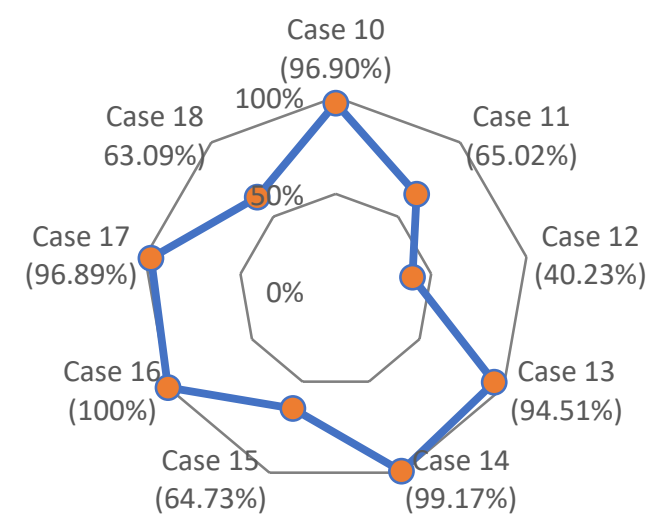

Fig. 2. $\mathrm{CH}_{3} \mathrm{OH}$ conversion of different cases for (a) $\mathrm{S} / \mathrm{C}=1.5$ and $(\mathrm{b}) \mathrm{S} / \mathrm{C}=2.0$.

Calculated in accordance with Eq. (5) and reported in Fig. 3, "hydrogen yield" values make better indicators of hydrogen productivity compared to hydrogen concentration because of the fact that the former are mutually comparable with a common denominator, the theoretical highest value of $3 \mathrm{~mol}$ (mol $\left.\mathrm{CH}_{3} \mathrm{OH}\right)^{-1}$.

Figure 3a shows the hydrogen yields under the condition of $S / C=1.5$, where Cases 1,5 , and 8 - all of which had a reaction temperature of $250^{\circ} \mathrm{C}$ or above - registered the highest hydrogen yields (2.52, 2.96, and 2.93, respectively, out of the theoretical ceiling of $3.0 \mathrm{~mol}\left(\mathrm{~mol} \mathrm{CH}_{3} \mathrm{OH}\right)^{-1}$. Fig. $3 \mathbf{b}$, on the other hand, shows the hydrogen yields obtained under the condition of $\mathrm{S} / \mathrm{C}=2.0$. Again, parallel patterns emerged with the number of cases achieving a hydrogen yield of $2.5 \mathrm{~mol}\left(\mathrm{~mol} \mathrm{CH}_{3} \mathrm{OH}\right)^{-1}$ or above increased. All experimental parameters and MSR results are reported in Table 1. 


\section{Table 1}

Configuration of L18 $(2 \times 3 \times 4)$ orthogonal array

\begin{tabular}{|c|c|c|c|c|c|c|c|c|c|c|}
\hline \multirow[b]{2}{*}{$\begin{array}{l}\text { Trail } \\
\text { no. }\end{array}$} & \multicolumn{4}{|c|}{ Conductions } & \multirow[b]{2}{*}{$\begin{array}{l}\mathrm{CO}_{2} \\
(\%)\end{array}$} & \multicolumn{5}{|c|}{ MSR } \\
\hline & $\begin{array}{l}\mathrm{Ni}-\mathrm{Cu} \\
\text { cat. } \\
(\%)\end{array}$ & $\begin{array}{l}\text { Reacting } \\
\text { temp. }\left({ }^{\circ} \mathbf{C}\right)\end{array}$ & $\begin{array}{l}\text { The flow rate of the } \\
\text { carrier gas } \\
\left(\mathrm{N}_{2}, \mathrm{~mL} / \mathrm{min}\right)\end{array}$ & $\begin{array}{l}\text { Steam/Carbon } \\
\text { ratio }(\mathrm{S} / \mathrm{C})\end{array}$ & & $\begin{array}{l}\text { CO } \\
(\%)\end{array}$ & $\begin{array}{c}\mathrm{CH}_{4} \\
(\mathrm{ppm})\end{array}$ & $\begin{array}{c}\text { Conversion } \\
\text { (\%) }\end{array}$ & $\begin{array}{l}\mathrm{H}_{2} \\
(\%)\end{array}$ & $\begin{array}{c}\mathrm{H}_{2} \text { yield } \\
(\mathrm{mol} / \mathrm{mol} \\
\left.\mathrm{CH}_{3} \mathrm{OH}\right)\end{array}$ \\
\hline 1 & 10 & 250 & 1,000 & 1.5 & 11.9 & 2.5 & 1522 & 88.85 & 37.69 & 2.52 \\
\hline 2 & 10 & 300 & 1,500 & 1.5 & 7.9 & 3.5 & 312 & 83.42 & 27.12 & 2.12 \\
\hline 3 & 10 & 200 & 2,000 & 1.5 & 7 & 2 & 18 & 75.25 & 24.22 & 2.25 \\
\hline 4 & 20 & 250 & 1,500 & 1.5 & 7.2 & 4.2 & 1627 & 80.27 & 29.55 & 2.21 \\
\hline 5 & 20 & 300 & 2,000 & 1.5 & 6.3 & 3.7 & 768 & 92.58 & 30.09 & 2.96 \\
\hline 6 & 20 & 200 & 1,000 & 1.5 & 11.7 & 2.3 & 237 & 80.16 & 38.23 & 2.36 \\
\hline 7 & 30 & 250 & 2,000 & 1.5 & 5.2 & 4.3 & 239 & 94.79 & 24.57 & 2.36 \\
\hline 8 & 30 & 300 & 1,000 & 1.5 & 9.8 & 5.2 & 3,766 & 100 & 39.74 & 2.93 \\
\hline 9 & 30 & 200 & 1,500 & 1.5 & 7.3 & 1.9 & 458 & 59.33 & 25.35 & 1.77 \\
\hline 10 & 10 & 250 & 1,000 & 2.0 & 12.4 & 2.4 & 1312 & 96.9 & 36.99 & 2.72 \\
\hline 11 & 10 & 300 & 1,500 & 2.0 & 7.2 & 2.2 & 214 & 65.02 & 26.27 & 1.96 \\
\hline 12 & 10 & 200 & 2,000 & 2.0 & 4.8 & 0.3 & 375 & 40.23 & 16.43 & 1.42 \\
\hline 13 & 20 & 250 & 1,500 & 2.0 & 7.4 & 4 & 743 & 94.51 & 29.06 & 2.56 \\
\hline 14 & 20 & 300 & 2,000 & 2.0 & 6.7 & 2.9 & 1217 & 99.17 & 24.67 & 2.88 \\
\hline 15 & 20 & 200 & 1,000 & 2.0 & 10 & 1.6 & 1129 & 64.73 & 36.96 & 2.24 \\
\hline 16 & 30 & 250 & 2,000 & 2.0 & 6.3 & 3.1 & 207 & 100 & 22.8 & 2.41 \\
\hline 17 & 30 & 300 & 1,000 & 2.0 & 9.5 & 4.9 & 2081 & 96.89 & 38.58 & 2.77 \\
\hline 18 & 30 & 200 & 1,500 & 2.0 & 7.12 & 2.4 & 458 & 63.09 & 27.44 & 2.01 \\
\hline
\end{tabular}


(a) $\mathrm{H}_{2}$ yield, $\mathrm{S} / \mathrm{C}=1.5$

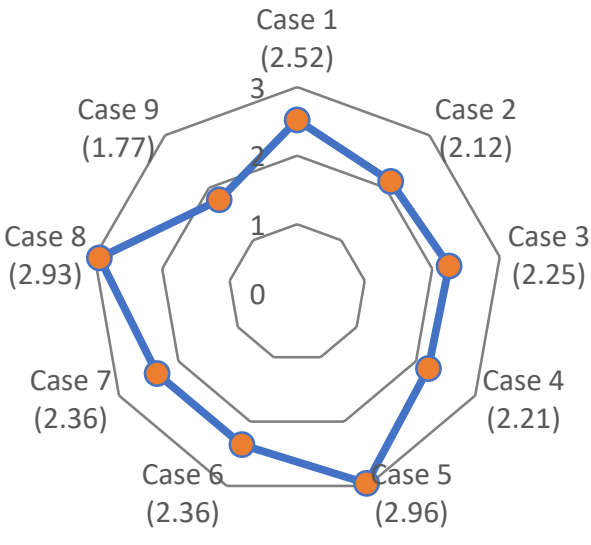

(b) $\mathrm{H}_{2}$ yield, $\mathrm{S} / \mathrm{C}=2.0$

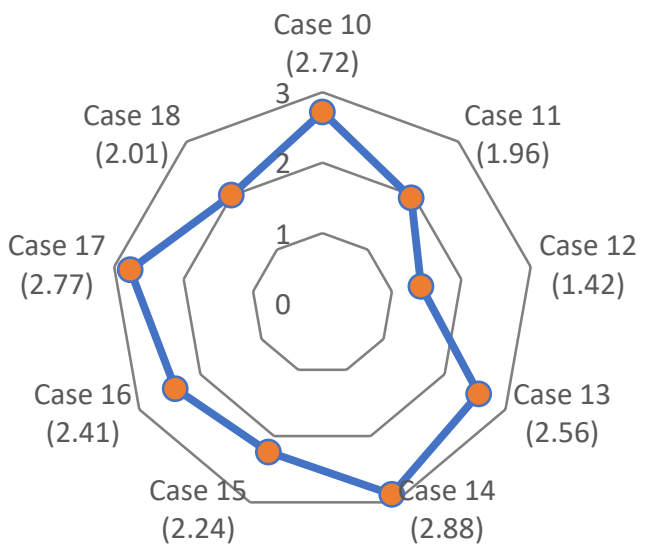

Fig. 3. $\mathrm{H}_{2}$ yields of different cases for (a) $\mathrm{S} / \mathrm{C}=1.5$ and (b) $\mathrm{S} / \mathrm{C}=2.0$.

\section{Conclusions}

The efficient conversion and high yield of hydrogen from methanol are critical to its feasibility as a clean carrier of energy. The key to conversion efficiency and hydrogen productivity lies in the adequate contact between the reactants and the catalyst. In order to investigate the relative impact of different factors on methanol-hydrogen conversion, four key experimental parameters were arranged into a Taguchi orthogonal matrix, which helped to discover patterns with a manageable number of experimental runs. According to ANOVA analysis and the Taguchi method, the temperature is the primary factor bearing on hydrogen productivity in the MSR process. In addition to this, the conversion efficiency and hydrogen productivity are attainable with $\mathrm{Ni}-\mathrm{Cu} / \mathrm{Al}_{2} \mathrm{O}_{3}$ composites as MSR catalysts in ultrasonic sprays. Owing to their high surface area, such catalysts helped achieve $96.9 \%$ methanol conversion, $36.9 \%$ hydrogen concentration, and $2.7 \mathrm{~mol} \cdot\left(\mathrm{mol} \mathrm{CH} \mathrm{CH}_{3} \mathrm{OH}\right)^{-1}$ hydrogen yield (with a theoretical ceiling of $\left.3.0 \mathrm{~mol}\left(\mathrm{~mol} \mathrm{CH}_{3} \mathrm{OH}\right)^{-1}\right)$ at $250{ }^{\circ} \mathrm{C}$.

\section{Acknowledgments}

The authors would like to acknowledge the financial support of the Ministry of Science and Technology, Taiwan, R.O.C., under the grant numbers MOST 108-2221-E-006-127-MY3 and MOST 109-2622-E-006-016-CC1, for this research.

\section{Nomenclature}

$\dot{n} \quad$ the molar flow rate $\left[{\left.\mathrm{mol} \mathrm{min}^{-1}\right]}^{2}\right.$

\section{References}

[1] E. Funk, J., 2001, "Thermochemical hydrogen production: past and present," International Journal of Hydrogen Energy, 26(3), pp. 185-190.

[2] Dincer, I., and Acar, C., 2015, "Review and evaluation of hydrogen production methods for better sustainability," International Journal of Hydrogen Energy, 40(34), pp. 11094-11111.

[3] Esswein, A. J., and Nocera, D. G., 2007, "Hydrogen Production by Molecular Photocatalysis," Chemical Reviews, 107(10), pp. 4022-4047.

[4] Kapdan, I. K., and Kargi, F., 2006, "Bio-hydrogen production from waste materials," Enzyme and Microbial Technology, 38(5), pp. 569-582.

[5] Agrafiotis, C., von Storch, H., Roeb, M., and Sattler, C., 2014, "Solar thermal reforming of methane feedstocks for hydrogen and syngas production-A review," Renewable and Sustainable Energy Reviews, 29, pp. 656-682.

[6] Durbin, D. J., and Malardier-Jugroot, C., 2013, "Review of hydrogen storage techniques for on board vehicle applications," International Journal of Hydrogen Energy, 38(34), pp. 14595-14617.

[7] Sá, S., Silva, H., Brandão, L., Sousa, J. M., and Mendes, A., 2010, "Catalysts for methanol steam reformingA review," Applied Catalysis B: Environmental, 99(1), pp. 43-57. 